\title{
THE CROATIAN CONSTITUTIONAL COURT AND THE EU CHARTER OF FUNDAMENTAL RIGHTS - A LIMBO BETWEN THE CHARTER, THE ECHR AND NATIONAL CONSTITUTION*
}

\author{
Helena Majić, MSc, Legal Adviser \\ The Constitutional Court of the Republic of Croatia \\ Trg svetog Marka 4, 10000 Zagreb \\ helena_majic@usud.hr; helenamajic@yahoo.com
}

\begin{abstract}
The Charter of Fundamental Rights of the European Union has been applied directly by the Croatian Constitutional Court since the decision No. U-I-1397/2015 (Act on Elections of the Representatives to the Croatian Parliament) rendered in 2015. Ever since it can be observed that the Charter has been consistently applied both in the proceedings of constitutional review in abstracto and in the proceedings initiated by a constitutional complaint (constitutional review in concreto), however, in a limited number of cases mostly concerning migrations or asylum. Therefore, this paper analyses the application of the Charter in the case law of the Croatian Constitutional Court and the method of interpretation pursued, with special reference to both its shortcomings and benefits. The paper also investigates the reasons for limited application of the Charter, even in those cases which would normally fall under the scope of application of EU law. The analysis indicates two distinct methodological approaches adopted by the Constitutional Court. The first one, where the Charter has been regarded as an interpretative tool only; and the second one, where the Charter has been found to be directly applicable vis-àvis individual rights inferred from the EU law. The latter approach, first followed in an asylum case No. U-III-424/2019 (X. Y.), had raised new questions on interpretation of the Charter (with respect to the Croatian constitutional framework) in the cases where the Charter's applicability ratione materiae overlaps with the Croatian Constitution and the (European) Convention for the Protection of Human Rights and Fundamental Freedoms, which to the day, in contrast to the Charter, has been consistently followed and therefore legally internalised by the Croatian Constitutional Court. Therefore, the paper also elaborates a new methodological approach adopted by the Croatian Constitutional Court in finding a way out of "limbo “ between the Charter, the ECHR, and the Croatian Constitution.
\end{abstract}

Key words: Croatian Constitutional Court, EU Charter of Fundamental Rights, ECHR, Croatian Constitution, migrations, asylum

The views expressed in this paper are those of the author and do not represent, nor do they reflect the views of the Constitutional Court. 


\section{INTRODUCTION: THE CROATIAN CONSTITUTIONAL COURT AND A DUAL CHARACTER OF THE EUROPEAN HUMAN RIGHTS SYSTEM}

Ever since the Republic of Croatia (hereinafter: RoC) had become a candidate for membership to the European Union (hereinafter: EU), a significant body of scholarly work and papers has been produced on the topic of a relationship between the Constitution of the $\mathrm{RoC}^{1}$ (hereinafter: Croatian Constitution) and the EU law. ${ }^{2}$ On the other side, there is only a limited body of research work on the topic of interpretative methods of the Croatian Constitutional Court (hereinafter: CCC) as a European court obliged to apply both the EU law and the (European) Convention for the Protection of Human Rights and Fundamental Freedoms ${ }^{3}$ (hereinafter: ECHR). ${ }^{4}$ Furthermore, some scholars have already tackled opened questions on the position of the Charter of Fundamental Rights of the EU ${ }^{5}$ (hereinafter: the Charter) in the Croatian legal order. ${ }^{6}$ However, the interpretative methods pursued by the CCC in the application of the Charter remain unexplored to this day, especially in the context of the CCC's duty to interpret and apply the ECHR which, in its scope of application, overlaps with the application of the Charter.

The principal goal of this paper is to give an overview of the CCC's case law on application of the Charter, with a special focus on the CCC's interpretative methods, all in the context of the CCC's role in a dual European system of human rights governed by both the Charter and the ECHR (with special reference to asylum cases). ${ }^{7}$ The research is divided in four parts: in the first one the paper provides

1 The Constitution of the Republic of Croatia, Official Gazette No. 56/1990, 135/1997, 113/2000, 28/2001, 76/2010, 5/2014.

2 See, among the latest papers: Smerdel, B., In Quest of a Doctrine: Croatian Constitutional Identity in the European Union, Zbornik Pravnog fakulteta u Zagrebu, Vol. 64 No. 4, 2014, pp. 513 - 554; Horvat Vuković, A., The Constitutional Court of the Republic of Croatia as a 'European' Court and the Preservation of National Standards of Fundamental Rights Protection, Zbornik Pravnog fakulteta u Zagrebu, Vol. 69, No. 2, 2019, pp. $249-276$.

3 Official Gazette, International agreements, No. 18/1997, 6/1999, 14/2002, 13/2003, 9/2005, 1/2006, $2 / 2010$

4 See, for example, Barić, S. The Transformative Role of the Constitutional Court of the Republic of Croatia - From the ex-Yu to the EU, Working paper no. 6 for Analitika Center of Social Research, Sarajevo, 2016, pp. 13 - 39, [https://bib.irb.hr/datoteka/971606.constitutional_court_croatia_1.pdf], Accessed 3 February 2021.

$5 \quad 2012$, OJ C 326/391.

6 See, for example, Selanec, G., The Role of the Charter in the Croatian Legal Order, in Palmisano G. (ed.), Making the Charter of Fundamental Rights a Living Instrument, Brill Nijhoff, Leiden, 2015, pp. 361-381.

7 For various aspects of interrelation between the ECHR and the EU's legal order, see Dzehtsiarou, K. et al., Human Rights Law in Europe: The Influence, Overlaps and Contradictions of the EU and the ECHR, Routledge, New York, 2014. 
for an overview and analysis of the application of the Charter in the cases of constitutional review in abstracto; then in the second part follows the same analysis of the constitutional review in concreto cases; in the third part the paper describes the interpretative methods pursued by the CCC in applying both the Charter and the ECHR; and in the final part the research ends with concluding remarks and recommendations on further development of the CCC's interpretative methods.

\section{THE CHARTER AND THE CONSTITUTIONAL REVIEW IN ABSTRACTO}

The decision in which the CCC had referred to the Charter's text for the first time was rendered in 2012 in the case no. U-I-448/2009 where the CCC was called to review Art. 10 of the Criminal Procedure $\mathrm{Act}^{8}$ regulating inadmissibility of the evidence obtained in violation of the right to human dignity. The CCC pointed out that human dignity, protected by Art. 1 of the Charter, „is the first indivisable and universal value" of the EU. ' The CCC had referred further to the ECHR and the case law of the European Court of Human Rights (hereinafter: ECtHR), as well as the case law of the German Constitutional Court. However, the assessment of the merits was not brought into a relation with the cited Art. 1 of the Charter. Taking into account several circumstances, e.g.; that the Charter was mentioned for the first time in a case of constitutional review in abstracto; the fact that decision in question predates the accession of the $\mathrm{RoC}$ to the $\mathrm{EU}$, which was at that time relevant to the applicability of the EU law ratione temporis; and especially the fact that, to this day, the EU law does not lay any rules on admissibility of the evidence in criminal proceedings ${ }^{10}$; it remains unclear why the CCC had decided to refer to the Charter in this specific case.

If the Charter was not applicable (at least) ratione materiae, it could be speculated, as the CCC had indirectly indicated, that Art. 1 of the Charter was mentioned in the context of common European values or even general principles of law common to many other constitutional traditions. However, the CCC's simple reference to the Charter in the latter case cannot be taken as an answer to the question whether the CCC had actually implied that the Charter's provision could be applied, and therefore intepreted as general principles guiding the court's method of interpretation, in the cases falling out of the scope of application of the EU law. A

Official Gazette, No. 152/2008, 76/2009, 80/2011.

9 U-I-448/2009 et al. (Criminal Procedure Act), 19.7.2012., see par. 44.4.

10 In this regard see the critical review of the EU law on admissibility of evidence in criminal proceedings, in Ligeti, K. et al., Admissibility of Evidence in Criminal Proceedings in the EU, The European Criminal Law Association's Forum, No. 3, publication by Max Planck Society for the Advancement of Science, Freiburg, 2020, pp. $201-208$. 
proof $d u$ contraire can be found in the CCC's order no. U-I-5600/2012, rendered a year later and only a few months prior to the accession, in the proceedings for review of the constitutionality of the Enforcement Act. ${ }^{11}$ The CCC elaborated that the alleged inconsistency of the Enforcement Act with Art. 53 - 54 of the Charter cannot be examined in the merits because at the relevant time the Charter had not entered into force in the RoC. ${ }^{12}$ This conclusion was reached in spite of the applicants' complaint that, by enacting the new Enforcement Act, the RoC had violated the obligations assumed by the pre-accession agreements which, under certain conditions, can be binding and therefore applicable ratione temporis to the continuing situations created prior to the accession. ${ }^{13}$ Furthermore, the doors opened to the broader scope of application of the Charter in constitutional review in abstracto had been closed by the CCC's first post-accession order no. U-I-3861/2013 instituting proceedings for review of the Value Added Tax Act ${ }^{14}$. The CCC had concluded that the Charter is applicable only to the situations where "the member states implement the EU law" ${ }^{15}$ In this regard, it is interesting to notice that the Charter was applied directly for the first time in the CCC's decision on the Act Ammending the Act on Elections of the Representatives to the Croatian Parliament (hereinafter: the Elections Act) ${ }^{16}$, in particular Art. 30 (22) regulating promotion and fair treatment by the electronic media of the candidates standing for elections. The CCC confirmed (most likely unintentionally) that the Elections Act implements Art. 11 of the Charter (freedom of expression), by simply citing in the court's assessment, and therefore accepting, the Government's preparatory proposal of the impugned law citing the Charter. ${ }^{17}$ However, it was obvious from the court's further assessment (referring to the relevant case law of the ECtHR) that no sources were available to it on the applicability of the EU law or the Charter to the national elections falling under the exclusive competence of the Member States (hereinafter: MS's). Even when the Government or the legislator fails to discern whether the Charter or the EU law has been implemented by national legislation, it is still advisable for the CCC to take over that task because

11 Official Gazzete, No. 112/2012.

12 U-I-5600/2012 (Enforcement Act), 23.4.2013., see par. 9.

13 The interpretation on inapplicability of the EU law or the Charter to the pre-accession situations was, to some extent, dubious. In this regard, see more in Martines, F., Direct Effect of International Agreements of the European Union, The European Journal of International Law, Vol. 25 no. 1, 2014, p. 139 and further; in respect of the RoC's pre-accession agreements, see in particular the CJEU's case C-277/19 (R. D. and A. D.), 26.9.2019., par. 29., and the case law cited thereto.

14 Official Gazette, No. 73/2013.

15 U-I-3861/2013, 16.7.2013., par. 6.

16 The Act Ammending the Act on Elections of the Representatives to the Croatian Parliament, Official Gazette, No. 19/2015.

17 U-I-1397/2015, 24.9.2015., par. 135. 
the CCC had previosuly limited the applicability of the Charter only to the situations where „the MS's implement the EU law“. By accepting the Government's argument that the Elections Act implements Art. 11 of the Charter, in spite of the fact that the situation in question was not governed by the EU law, the CCC had prejudiced the applicability of the Charter for the following decisions rendered in comparable situations.

Regardless of the obvious inconsistencies in applying the Charter in the situations that are not governed by the EU law, to this day the CCC has not explicitly stated that the Charter (and the supporting case law of the Court of Justice of the EU; hereinafter: CJEU) shall be applied or interpreted, at least as a general principle of law or a common constitutional tradition, in the situations falling out of the scope of application of EU law. However, the possibility of the latter, less formal approach to the application of the Charter as an interpretative legal tool and source, has not been ruled out, thankfully to the dissenting opinions of several judges of the CCC, indicating that the consensus on the latter issue has not been reached. ${ }^{18}$

Contrary to the decision on the Elections Act, in other cases the CCC had disregarded either the Government's or the applicants' arguments that the impugned law implements either secondary law of the EU or the Charter, even where the EU law was manifestly applicable. In the decision on the The Act Ammending and Supplementing the Consumer Protection Act (hereinafter: the Consumer Protection Act $)^{19}$ the CCC cited the applicants in so far as they had complained that the Government, by enacting the impugned law on the consumers' right to conversion of Swiss franc loans, had violated Art. 63 of the Treaty on the Functioning of the European Union. ${ }^{20}$ The CCC cited as well the applicants' complaints as to the method of implementation of the EU directives, that was, in their view, manifestly erroneus and disproportionate, inter alia, due to the retrospective effect of

18 See, for example, the dissenting opinions of the judges advocating for reception of the general principles of EU law or the Charter as a legal transplant in various situations where the EU law was not neccessarily directly applicable, in the following cases: U-III-1267/2015 (GONG - the right of access to classified informations), 21.11.2017., a dissenting opinion of the judges Abramović, Kušan and Selanec; U-I-60/1991 et al. (Termination of pregnancy), 21.2.2017., a dissenting opinion of judge Šumanović on the interpretation of Art. 1 of the Charter and the CJEU's ruling in the case C-34/10 (Brüstle), GC, 18.11.2011., par. 11.3.; U-I-1092/2017 (Act on Direct Payments for Employment), 10.7.2018., a dissenting opinion of the judges Kušan and Selanec on the application of the principle of non-discrimination in similar situations governed by the EU's non-discrimination rules in the area of employment.

19 Official Gazette No. 102/2015.

$20 \quad$ 2012, OJ C 326. 
the impugned law. ${ }^{21}$ In its assessment ${ }^{22}$, the CCC had not advanced further the Government's argument that the contested law implements Art. 38 of the Charter (consumer protection), but had only accepted the Government's observation that the impugned provisions on the conversion of Swiss franc loans do not implement directly the Directive on credit agreements for consumers relating to residential immovable property ${ }^{23}$. The CCC recognized that the situation in question possibly falls under the scope of application of the Directive on unfair terms in consumer contracts ${ }^{24}$, but nevertheless the CCC neglected a possibility to review the impugned law from the perspective of a consumer's right to an effective legal remedy as guaranteed by Art. 47 of the Charter. ${ }^{25}$ If Art. 47 of the Charter was applied, the latter approach would have been verified by the CJEU only a year later in the case $S z i b e r^{26}$, concerning the conversion of loans, where the CJEU decided to interpret the Directive on unfair terms in consumer contracts in connection to Art. 47 of the Charter, by pointing out that „it is therefore appropriate, having regard to the subject matter ..., to interpret that directive, read in the light of the relevant provisions of the Charter, in particular Article 47 thereof, which enshrines the right to effective judicial protection ". ${ }^{27}$ The CJEU went even further, by using the language of "positive obligations of the MS's" that is more inherent the ECtHR's case law, therefore concluding that „it is apparent from Article 7(1) of Directive $93 / 13, \ldots$, that the MS's must ensure that judicial and administrative bodies have adequate and effective means to prevent the continued use of unfair terms in contracts concluded with consumers by sellers or suppliers" ${ }^{28}$

In view of the Sziber case, it appears that the constitutional review of the Consumer Protection Act was a missed opportunity for implementing the Charter as an intepretative tool in the test of proportionality of the impugned provisions, as it was obvious that the measure taken by the Government had a legitimate aim in providing an effective legal remedy for eliminating the consequences of unfair

${ }_{21}$ U-I-3685/2015 (Consumer Protection Act), 4.4.2017.; see in particular par. 11.-11.1., 11.3.-11.4., 11.7.-11.8., 11.11.

22 Ibid., see par. 26. -42.

23 Directive 2014/17/EU of the European Parliament and of the Council of 4 February 2014 on credit agreements for consumers relating to residential immovable property and amending Directives 2008/48/EC and 2013/36/EU and Regulation (EU) No 1093/2010, 2014, OJ L 60 /34.

24 Council Directive 93/13/EEC of 5 April 1993 on unfair terms in consumer contracts , 1993, OJ L $95 / 29$.

25 U-I-3685/2015, op. cit., see par. 18.1. and 30.

26 C-483/16 (Sziber), 31.5.2018.

27 Ibid., see par. 29.

28 Ibid., see par. 33.; For a thorough analysis of the Sziber case, see Gomboš, K., Europeanisation effects in the court jurisprudence, International and Comparative Law Review, Vol. 19, No 1., 2019, pp. 265-266. 
terms in consumer credit agreements. Furthermore, the fact that the CJEU had ruled on the "right to conversion" only a year after the CCC's decision, indicates that the CCC could have and should have reconsidered a potential applicability of the Charter in specific circumstances of the latter case.

However, a novel approach to applying the Charter proprio motu in constitutional review in abstracto has been developed in the case no. U-I-2911/2017 where the applicants contested Art. 434 of the Public Procurement Act ${ }^{29}$ regulating judicial control of the procedures conducted by the State Commission for Supervision of Public Procurement Procedures (hereinafter: SCSPPP). The applicants complained that the impugned provisions, setting up a single-instance court mechanism for the judicial review of the SCSPPP (that being the High Adminstrative Court as both the court of first instance and the court of last resort), do not comply with Art. 18 of the Croatian Constitution (right of appeal) and Art. 29 of the Croatian Constitution (right to a fair trial and of access to a court). They argued that the administrative courts of first instance were left out of the scheme, thus depriving the applicants of a possibilty to have their appeal decided by the High Administrative Court as a court of second instance. The CCC acknowledged that the case falls under the scope of application of the Directive on improving the effectiveness of review procedures concerning the award of public contracts ${ }^{30}$ and therefore examined the complaints by applying Art. 47 of the Charter. Starting from the interpretation provided by the CJEU in the case Combinatie Spijker Infrabouw-De Jonge Konstruktie $e^{31}$, the CCC pointed out that Art. 47 of the Charter compels the MS's to set up effective legal remedies in the area of public procurement, but at the same time the MS's enjoy a certain margin of appreciation in the choice of the procedural guarantees. From the text of the Directive and the CJEU's judgment rendered in the case Diouf ${ }^{2}$, the CCC concluded that Art. 47 of the Charter affords an individual a right of access to a court, but not to a number of levels of jurisdiction. ${ }^{33}$ The Diouf judgment was a preliminary ruling interpreting the Asylum Procedures Directive $2005^{34}$ and therefore had no connection whatsoever to the Directive on improving the effectiveness of review procedures concerning the

29 Official Gazette, No. 120/2016.

30 Directive 2007/66/EC of the European Parliament and of the Council of 11 December 2007 amending Council Directives 89/665/EEC and 92/13/EEC with regard to improving the effectiveness of review procedures concerning the award of public contracts, 2007, OJ L 335/31.

31 C-568/08 (Combinatie Spijker Infrabouw-De Jonge Konstruktie), 9.12.2010.

32 C-69/10 (Diouf), 28.7.2011.

33 U-I-2911/2017 (Public Procurement Act), 5.2.2019., par. 19.1. - 19.2.

34 Directive 2005/85/EC of 1 December 2005 on minimum standards on procedures in Member States for granting and withdrawing refugee status, 2005, OJ L 326/13. 
award of public contracts. ${ }^{35}$ However, it must noticed that, to this day, the CJEU has not dealt with comparable issues of single-instance court mechanisms in the area of public procurement. Therefore, no other choice was left to the CCC but to resort to transplanting the case law developed in the area of asylum procedures. On the other side, a due regard could have been given to the case Star Storage $e^{36}$ where the CJEU had established the general criteria limitation of the right to an effective remedy before a court (within the meaning of Art. 47 of the Charter) in public procurement procedures. ${ }^{37}$

A similar situation where the Charter was interpreted by the CCC on its own motion emerged again in the order on constitutionality of Art. 62 of the Penal Code ${ }^{38}$ regulating extension of the limitation periods for the offences, that was challenged by the applicants complaining of its incosistency with the nullum crimen sine lege principle. As the impugned provision is generally applicable to all offences, this case falls under the scope of application of the EU law as it has been argued by the Advocate General Bot in his opinion delivered in the case Taricco II ${ }^{39}$ (that is confronting the requirement of effectiveness of the EU law with the principles of legality and proportionality of criminal offences and penalties protected by Art. 49 of the Charter). In contrast to the case Taricco II where the Italian Constitutional Court had decided to seek a preliminary ruling from the CJEU, that would further clarify the CJEU's interpretation of the earlier case Taricco $I^{40}$, the CCC did not seek a preliminary ruling from the CJEU, but rather decided to interpret Art. 49 of the Charter and the Tarrico I judgment on its own motion. ${ }^{41}$ However, in the first few days following the CCC's decision, the CJEU rendered a judgment in the case Taricco II in which it opted for a novel approach to the intepretation of Art. 49 of the Charter in connection to Art. 7 ECHR and has thus, in part, departed from the position taken in Taricco I judgment. ${ }^{42}$

Therefore, by taking into account the earlier decision on the Consumer Protection Act, and now the fact that the Italian Constitutional Court sought a preliminary

35 As to the relevance of the latter case in the context of asylum procedures, see Zalar, B., Comments on the Court of Justice of the EU's Developing Case Law on Asylum, International Journal of Refugee Law, Vol. 25, No.2, 2013, pp. 377-381.

36 C-439/14 and C-488/14 (Star Storage), 15.9.2016.

37 Ibid., see par. 49.

38 Official Gazette, No. 25/2011, 144/2012, 56/2015, 61/2015, 101/2017.

39 C-42/17 (Taricco II), AG's opinion, 18.7.2017.

40 C-105/14 (Taricco I), GC, 8.9.2015.

41 U-I-3826/2013 et al., 28.11.2017., see par. 16.1., 18., 23.

42 For a detailed interpretation and analysis of the Taricco II case, see Materljan, G.; Materljan, I., Predmet Taricco II i pitanja na vagi: ustavno načelo zakonitosti u kaznenom pravu i djelotvornost prava Europske unije, Hrvatski ljetopis za kaznene znanosti i praksu (Zagreb), Vol. 26, No 2, pp. 503 -528. 
ruling in a situation comparable to that of the CCC in the Penal Code case, it can be observed that the CCC is not activating the preliminary reference procedure nor engaging in the judicial dialogue with the CJEU, even where it is appropriate and there is no dispute over the applicability of the EU law, nor the Charter. In the context of the Penal Code case, a preliminary ruling of the CJEU could have shed a new light on the application of the nullum crimen sine lege principle, as it has eventually happened in the Taricco II case. ${ }^{43}$ Finally, in the joined cases U-I2854/2018 and U-I-2855/2018, concerning the compatibility of the Croatian Qualifications Framework with the European Qualifications Framework, where the applicants complained that awarding different qualifications to the students in comparable situations was not reasonable nor proportionate, several judges dissented from the majority by arguing that the CCC had to refer the questions brought before it to the CJEU for a preliminary ruling. ${ }^{44}$

\section{THE CHARTER AND THE CONSTITUTIONAL REVIEW IN CONCRETO}

The CCC referred to the Charter for the first time in the proceedings instituted by an individual complaint of an applicant complaining that he was unlawfully deprived of liberty in the proceedings for execution of the European arrest warrant. By its decision no. U-III- 351/2014 (Perkovic) the CCC accepted, according to the CJEU's ruling rendered in the case Radu $u^{45}$, that all domestic proceedings for execution of the European arrest warrant must comply with the requirement of respect for personal liberty protected by Art. 6 of the Charter. ${ }^{46}$ Even though this was the very first case of constitutonal review in concreto where the Charter was directly applicable, it has gone unnoticed that the CJEU had actually examined the Radu case by referring to Art. 47 (right to a fair trial) and Art. 48 of the Charter (right of defence), therefore excluding a potential applicability of Art. 6 of the Charter taken alone. ${ }^{47}$ In its own decision, the CCC did not further apply the Charter or the CJEU's case law to the assessment of the alleged violation of human rights. However, the principal reason thereto is disclosed by the fact that the applicant's complaint was not substantiated in respect of the application of the Charter. Therefore, the comparable situations where, on one side the CCC accepts the applicability of the Charter, but on the other side does not give any interpreta-

\footnotetext{
43 See C-42/17 (Taricco II), GC, 5.12.2017., par. 54. - 55., 60. - 62.

44 U-I-2854/2018, U-I-2855/2018 (Croatian Qualifications Framework), 10.3.2020., see a dissenting opinion of the judges Abramović, Kušan and Selanec.

45 C-396/11 (Radu), GC, 29.1.2013.

46 U-III- 351/2014 (Perkovic), 24.1.2014., par. 13.1.

47 See C-396/11 (Radu), GC, 29.1.2013., par. 30. - 32.
} 
tions of the Charter's provision in the assessment of the alleged violation of human rights due to the applicants' failure to refer to the relevant provisions of the Charter or the case law of the CJEU, have repeated again in the CCC's case law. ${ }^{48}$

Therefore, it does not appear that the CCC will pursue a detailed approach to the application of the Charter or the CJEU's case law thereto if the applicant does not substantiate his or her complaint thereof.

The latter method of limiting the scope of the constitutional review in concreto was confirmed once again in respect of the Charter by the decision no. UIII-6958/2014 (S. A. K.) where the applicant, an asylum seeker, complained of inability to access free legal assistance and to have the costs of a legal representation reimbursed. The applicant referred to Art. 47 of the Charter, but omitted to point out any of the CJEU's ruling thereto. ${ }^{49}$ Taking into account the relevant provisions of Art. 9 of the Reception Conditions Directive ${ }^{50}$, the CCC briefly concluded, without referring to the CJEU's case law, that the applicant's case had not raised any relevant questions as to the potential inconsistencies with the requirements of Art. 47 of the Charter. ${ }^{51}$ Furthermore, the CCC had not conducted an inquiry into availability of free legal assisstance or legal representation to the asylum seekers in the RoC. This approach may appear as a restrictive one, especially if confronted with the principle of iura novit curia and a very specific nature of an asylum seeker's complaint of violation of human rights. However, pursuant to Art. 65 of the Constitutional Act on the Constitutional Court of the $\mathrm{RoC}^{52}$, the applicant bears a duty of substantiating an alleged violation of human rights. Therefore, the unsubstantiated claims shall not be examined in the merits, but shall be declared inadmissible instead. ${ }^{53}$ In this respect the examination method of the CCC is mirroring the settled case law of the ECtHR on manifestly ill-founded complaints. ${ }^{54}$ On the other side, if the same method was pursued in each case consistently, by disregarding the nature of different violations of human rights that can be brought

48 See, for example, case no. U-III-3468/2018 (ORCA), 18.11.2018., par. 14.5., where a reference was made to the right to strike as a general principle of the EU law and a fundamental right according to the CJEU's interpretation in the case C-438/05 (Viking), GC, 11.9.2007.

49 U-III-6958/2014 (S. A. K.), 27.2.2018., see par. 1.2. in connection to par. 4.

50 Directive 2013/33/EU of the European Parliament and of the Council of 26 June 2013 laying down standards for the reception of applicants for international protection (recast), 2013, OJ L 180/96.

$51 \quad$ S. A. K., op. cit., see par. 6.1.2. and 8.

52 Official Gazette, No. 99/1999, 29/2002 i 49/2002.

53 See in that regard decision no. U-III-4150/2019 (Raiffeisenbank and Others), 3.2.2021. par. 60.1. and 60.3 .

54 See more in the ECtHR's Practical Guide on Admissibility Criteria, Council of Europe, Strasbourg, 2021, par. 74.; [https://www.echr.coe.int/documents/admissibility_guide_eng.pdf], Accessed 1 April 2021. 
before the court, it would hardly meet the requirements of the ECtHR's case law on the distribution of proof between an asylum seeker and the Government or the ECtHR's position on collecting the evidence proprio motu in the asylum cases. ${ }^{55}$ In this regard, the shortcomings of the CCC's assessment method in the $S$. $A$. $K$. case have become particularly noticeable after the case no. U-IIIBi-1385/2018 (Hussainkhel I) where the applicants detained in the reception centre complained of having been denied access to a lawyer and the conditions in the reception center that had not met the requirements of respect for human dignity (Art. 3 ECHR). ${ }^{56}$ In contrast to the $S . A . K$. case, in the Hussainkhel I case the CCC had verified relevant evaluation reports on the access to the reception centre and the conditions of reception. ${ }^{57}$ But on the other side, the CCC did not observe that the situation before it was governed by Art. 9 (guarantees for detained applicants) and Art. 10 (conditions of detention) of the Reception Conditions Directive, in connection to Art. 4 (prohibition of inhuman or degrading treatment) and Art. 47 of the Charter (right to a fair trial and effective legal remedy), but had only referred to the text of Art. 18 (right to asylum) and Art. 19 of the Charter (non-refoulement). ${ }^{58}$

However, the follow-up cases of in the area of asylum or migrations demonstrated a gradual shift towards a different approach where the CCC, on its own motion, applies the Charter directly.

In the case no. U-III-208/2018 (Oral I), the applicant, a Turkish citizen who had already been granted an asylum in the Swiss Confederation, was detained in the $\mathrm{RoC}$ on the arrest warrant of the Turkish Republic. He complained that the Supreme Court's decision uphelding an order of extradition to the Turkish Republic had violated Art. 31 of the Croatian Constitution prohibiting extradition of individuals who are residing lawfully in the $\mathrm{RoC}$ or the $\mathrm{EU}$, as he was already granted an asylum in the Swiss Conferedation. Furthermore, he argued that the extradition would contravene the principle of non-refoulement in connection to Art. 2 (right to life) and Art. 3 (prohibiton of torture and degrading treatment) ECHR. In his complaints the applicant did not refer to the Charter in any way. ${ }^{59}$ However, the CCC had applied on its own motion the principle of mutual confidence and Art. 4 of the Charter (prohibition of inhuman or degrading treatment), as interpreted by the CJEU in the case of N.S. and Others ${ }^{60}$. Starting from the Council Deci-

\footnotetext{
55 See F.G. $v$ Sweden, 43611/11, GC, 23.3.2016., par. 127; and J. K. and Others v. Sweden, 59166/12, GC, 23.8.2016., par. $91-98$.

56 U-IIIBi-1385/2018 (Hussainkhel I), 18.12.2018., par. 15.1. - 15.2.

57 Ibid. par. 23., 34.

$58 \quad$ Ibid., par. 20.3 .

59 U-III-208/2018 (Oral 1), 10.7.2018., see par. 15. - 15.6.

60 C-411/10 and C-493/10 (N. S. and Others), GC, 21.12.2011.
} 
sion 2008/147/EC of 28 January $2008^{61}$ and the Council Decision 2009/487/EC of 24 October $2008^{62}$ integrating the Swiss Confederation into the Dublin system, the CCC found that the fact of having been granted an asylum in the Swiss Confederation prevents the applicant's extradition to the Turkish Republic. ${ }^{63}$ The CCC further noticed that the Supreme Court had attached a decisive weight to the fact that the Swiss Confederation is not a MS of the EU, without investigating the position held by the Swiss Confederation in the Dublin system according to the decisions adopted by the Council. For that reason, the CCC found further a violation of Art. 141.c of the Croatian Constitution regulating the duty of all public authorites to implement directly the EU law and the legal acts adopted by the institutions of the EU. ${ }^{64}$

\section{THE CROATIAN CONSTITUTIONAL COURT IN A LIMBO BETWEEN THE CHARTER AND THE ECHR}

Following the developments in applying the Charter proprio motu, the CCC got confronted with a dilemma on how to approach the cases where both the ECHR and the Charter were applicable, especially in the context of a complex interrelation between the ECHR system and the legal order of the EU. The so called Bosphorus doctrine on the rebuttable presumption of equivalent protection had enabled the ECtHR to rebut the presumption of equivalence, leading that court to review in the merits the conformity of the EU law with the ECHR (as the standards of protection afforded to an individual by the EU law do not have to be necessarily the same as those of the ECHR.) ${ }^{65}$ On the other side, the CJEU has

${ }^{61}$ 2008/147/EC: Council Decision of 28 January 2008 on the conclusion on behalf of the European Community of the Agreement between the European Community and the Swiss Confederation concerning the criteria and mechanisms for establishing the State responsible for examining a request for asylum lodged in a Member State or in Switzerland, 2008, OJ L 53/3.

62 2009/487/EC: Council Decision of 24 October 2008 on the conclusion of a Protocol between the European Community, the Swiss Confederation and the Principality of Liechtenstein to the Agreement between the European Community and the Swiss Confederation concerning the criteria and mechanisms for establishing the State responsible for examining a request for asylum lodged in a Member State or in Switzerland, 2009, OJ L 161/6.

63 U-III-208/2018 (Oral I), 10.7.2018., see par. 23.1. - 24., 26.

64 Ibid., see p. 27. -28.

65 See more on the Bosphorus doctrine and its development in Gragl, P., An Olive Branch from Strasbourg? Interpreting the European Court of Human Rights' Resurrection of Bosphorus and Reaction to Opinion 2/13 in the Avotin, Case: ECtHR 23 May 2016, Case No. 17502/07, Avotinš v Latvia, European Constitutional Law Review, Vol. 3, No. 3, pp. 551-567; and Kuhnert, K., Bosphorus - Double standards in European human rights protection?, Utrecth Law Review, Vol. 2, No. 2, 2006, pp. 177-189; For the cases where where the presumption was rebutted, see for example Michand v. France, 12323/11, 6.12.2012., par. 113 - 115; In the asylum cases, it should be borne in mind that the presumption of equivalent protection has been "diluted" and it is not applicable, even where the public authorities of 
been interpreting the ECHR as well; in the pre-Charter period in the context of the general principles of the EU law; and in the post-Charter period in accordance to Art. 52.3 of the Charter laying down an equivalent protection principle in the EU law by proclaiming that the meaning and scope of the fundamental rights guaranteed by the Charter shall be the same as those laid down by the ECHR. From there on the creators of the Charter went further by pointing out that this provision shall not prevent the EU law providing more extensive protection.

In the middle of a limbo described above is the CCC who, pursuant to Art. 134 of the Croatian Constitution and the settled case law, finds the ECHR to be directly applicable in the proceedings before all domestic courts, and especially the CCC. ${ }^{66}$ At the same time, the landmark decision rendered in the case Oral I, finding a violation of Art. 141.c of the Croatian Constitution if a domestic court fails to implement the EU law (the Charter) directly, had also created a duty of applying the Charter directly where applicable. Therefore, the post-accession CCC is now in a triangle between the ECtHR and the CJEU - obliged to observe the standards afforded to the protection of human rights by both European courts.

The CCC decided to verify proprio motu the equivalence of the standards of protection afforded by the ECHR and the Charter in a landmark decision rendered in the joined cases no. U-III-424/2019 and U-III-1411/2019 (X. Y.), concerning an Iraqi national whose application for asylum was rejected as unfounded (unsubstantiated), and a subsuquent application was rejected as inadmissible. The aplicant complained, inter alia, that under Croatian law he had been deprived of the right to an effective legal remedy capable of suspending the execution of a deporation order that was issued following the dissmissal of his subsequent application for asylum, whereas the appelate proceedings before the High Administrative Court, as a court of second instance, were still pending. Furthermore, the applicant argued that he would be deported to Iraq without having his appeal finally determined by the High Administrative Court. The CCC first examined whether the ECHR guarantees the right to a legal remedy with an automatic suspensory effect in the second instance of judicial proceedings. It was established, according to the judgments rendered in the cases De Souza v. France ${ }^{67}$ and A. M. v. Nether-

the Dublin system act within the authority provided to them by the Dublin regulations, if the ECtHR succeeds at establishing that the EU law had afforded them a margin of appreciation which enables them to exercise a public authority in compliance with the ECHR. In that respect see in particular the landmark judgment in M.S.S. v. Belgium and Greece, 30696/09, GC, 21.1.2011., par. 339 - 340.

${ }_{66}$ See in particular Habulinec and Filipović v. Croatia, 51166/10, 4.6.2013., par. 11; and the CCC's case no. U-III-2864/2016 (Đomlija), 23.5.2019., par. 18.

67 De Souza v. France, GC, 22689/07, 13.12.2012. 
lands $^{68}$, that Art. 13 ECHR does not compel the signatories to the ECHR to set up a second level of appeal before administrative courts. ${ }^{69}$ In so far, the applicant's complaints as described above could have been rejeceted as manifestly ill-founded (inadmissible), if the CJEU had not established, on the basis of Art. 47 of the Charter, a higher level protection in respect of an automatic suspensory effect of the appelate proceedings. In the case Staatssecretaris van Veiligheid en Justitie (suspensory effect of the appeal) ${ }^{70}$ the CJEU had determined, in line with the case law of the ECtHR, that the appeal submitted with the court of second instance does not need to have an automatic suspensory effect. However, according to the principle of eqivalence stemming from Art. 47 of the Charter, the CJEU imposed onto the domestic courts an additional duty to verify whether the legal remedies, provided by domestic law in other comparable procedures, have an automatic suspensory effect. Thus because the principle of equivalence requires an equal treatment of claims based on a breach of a national law and of similar claims based on a breach of the EU law. ${ }^{71}$ Therefore, the CCC had conducted a test of equivalence according to the criteria established by the CJEU. By comparing the legal remedies available to the foreigners pursuant to the Act on Foreigners ${ }^{72}$ and the Act on International and Temporary Protection ${ }^{73}$, the CCC had reached a conclusion that the Act on International and Temporary Protection, by implementing directly the Asylum Procedures Directive 2013 ${ }^{74}$, provides for a higher degree of legal protection to the asylum seekers when compared to the foreigners residing (un)lawfully in the $\mathrm{RoC}$ pursuant to the Act on Foreigners. Thus because the complaint submitted with an administrative court of first instance by an asylum seeker has an automatic suspensory effect enabling them to reside lawfully in the RoC until the complaint has been determined by that court, whereas the complaint submitted with an administrative court of first instance by a foreigner who had not applied for asylum does not have the same effect. ${ }^{75}$

Furthermore, in the $X . Y$. case the CCC had examined and determined (though not explicitly, but on the methodological level) the equivalence between the ECHR and the EU law in respect of the principle of ex nunc evaluation of an asylum ap-

\footnotetext{
68 A. M. v. Netherlands, 29094/09, 5.7.2016.

69 U-III-424/2019 and U-III-1411/2019 (X. Y. - deporation to Iraq), 17.12.2019., see in detail pp. 123 127.

70 C-180/17 (Staatssecretaris van Veiligheid en Justitie - suspensory effect of the appeal), 26.9.2018.

71 X. Y. - expulsion to Iraq, op. cit., see in detail par. 128. - 137.

72 Official Gazette, No. 130/2011, 74/2013, 69/2017, 46/2018.

73 Official Gazette, No. 70/2015, 127/2017.

74 Directive 2013/32/EU of the European Parliament and of the Council of 26 June 2013 on common procedures for granting and withdrawing international protection, 2013, OJ L 180/60.

75 X. Y. - expulsion to Iraq, op. cit., see in detail pp. $138-146$.
} 
plication protected by Art. 46 of the Asylum Procedures Directive 2013 and Art. 47 of the Charter. The applicant had also complained that his return to Iraq would contravene the non-refoulement principle (Art. 2 and 3 ECHR), whereas the administrative courts failed to examine the general risks in Iraq and the applicant related specific risk - an alleged persecution by a Shia militia. In that regard the CCC accepted that the assessment of the Ministry of Interior and administrative courts, as to the specific risks the applicant would face if he was deported to Iraq, was somewhat erroneus. ${ }^{76}$ Furthermore, the CCC took into account the passage of time between the first application for asylum and the date of the CCC's decision, as well as the subsuquent evidence produced by the applicant. ${ }^{77}$ According to Art. 46 of the Asylum Procedures Directive 2013 and Art. 47 of the Charter as intepreted by the Diouf judgment mentioned above, the MS's are obliged to secure a judicial review of the asylum cases based on the ex nunc principle, but this requirement applies consistently to the courts of first instance only. Therefore, the Asylum Procedures Directive 2013 does not impose any specific procedural requirements on the proceedings before a constitutional court. In that regard, and due to the erroneous assessment given by the lower courts, the CCC could have decided to remit the case to an administrative court of first instance for a new trial, as it had already done in the case no. U-III-557/2019 (A.B. $)^{78}$, therefore prolonging the uncertainty of the applicant's situation. However, following the methodological approach of the ECtHR in the cases F. G. v. Sweden and J. K. v. Sweden ${ }^{79}$, the CCC applied the principle of ex nunc evaluation as it is interpreted by the $\mathrm{ECtHR}^{80}$, consulted the relevant country reports and therefore examined proprio motu the general situation in Iraq, the applicant allegations as to the specific risks he would face if deported, and in the end the possibility of removal of the risks by internal relocation. ${ }^{81}$ Even though the applicant's complaints were rejected as unfounded, the CCC had nevertheless decided on the applicant's asylum application in the merits by applying the principle of ex nunc evaluation, providing him with a fully effective legal remedy within the meaning of Art. 13 ECHR and Art. 47 of the Charter. On the other side, if the CCC finds, by applying the ex nunc principle, that the complaints of an asylum seeker are founded, the decision in the

$76 \quad$ Ibid., see in detail par. $73 .-74$.

77 Ibid., see in detail par. 66., 86.

78 U-III-557/2019 (A. B. - expulsion to Iraq)., 11.9.2019., see par. 5.14. as to the CCC's order to the lower court to examine general situation in Iraq and applicant related specific riks.

79 As to the general principles on ex nunc evaluation of the complaints raised under Art. 2 and 3 ECHR, see in detail ibid., par. 56.3. - 56.7.

80 For a detailed review of the factors relevant for ex nunc assessment, as interpreted by the ECtHR, see Blöndal, E. K.; Arnardóttir, O. M, Non-Refoulement in Strasbourg: Making Sense of the Assessment of Individual Circumstances, Oslo Law Review, Vol. 5, No. 3, 2018, pp. 147-174.

81 Ibid., see in detail par. 60. - 108. 
$X . Y$. case has enabled the CCC to determine the applicant's claim finally. When the CCC remits the case to a lower administrative court, an application for asylum must be decided according to the CCC's final and binding interpretation. Therefore, the methodological approach adopted by the ECtHR provides the asylum seekers with a higher standard of protection in the proceedings before the CCC, than the standard of protection they would be afforded by applying the formalistic approach of the CJEU in applying Art. 47 of the Charter. For that reason, in the latter part of the decision rendered in the $X$. $Y$. case, the CCC had not referred to the Charter nor the CJEU's case law thereto.

However, a comparative method in applying both the Charter and the ECHR has not become a consistent method of interpretation. A year after the $X$. $Y$. case, the CCC rendered a decision in the case of constitutional review in abstracto, elaborating in details the requirements imposed by the Charter as to the deportation of the foreigners, but on the other side, without examining the standard of protection afforded by the ECHR in comparable situations. In the case no. U-I-1007/2012 et al. where the CCC was called to examine Art. 5 of the Act on Foreigners ${ }^{82}$ in so far as it provides that the deportation order on the grounds of national security shall not be reasoned. The applicant claimed that the impugned provision contravenes the principle of effective judicial protection, thus because a foreigner may be deported without knowing the reasons thereto. In spite of the extensive assessment of the CJEU's case law developed on the basis of Art. 47 of the Charter, and a thorough examination of procedural safeguards provided by domestic law ${ }^{83}$, the CCC had not verified whether the impugned provisions satisfy the requirements first established by the ECtHR in the case Al-Nashif v. Bulgaria ${ }^{84}$ as to the right to a reasoned decision of the foreigners deported for national security reasons, nor the general principles as to the effectivenes of judicial control in such cases that had been summarized in the case $X . v$. Sweden ${ }^{85} .{ }^{86}$

Attention must be brought to the fact that all signatory parties to the ECHR can fulfil their positive (procedural) obligations based on Art. 2 and 3 ECHR in connection to Art. 1 ECHR, only if domestic laws are of a certain quality capable of satisfying the procedural requirements imposed by the latter provisions of the ECHR, that may be different (more or less stringent) than the procedural re-

\footnotetext{
82 Act on Foreigners, No. 130/2011, 74/2013, 69/2017, 46/2018.

83 U-I-1007/2012 et al. (Act on Foreigners), 24.6.2020., see in particular par. 13. - 25.

84 Al-Nashifv. Bulgaria, 50963/99, 20.6.2002., see in particular par. 137. - 138.

${ }^{85}$ X. v. Sweden, 36417/16, 9.1.2018., see in particular par. 46 - 51.

86 For an overview of national security related immigration cases in the European context, see more in Chlebny, J., Public Order, National Security and the Rights of Third-Country Nationals in Immigration Cases, European Journal of Migration and Law, Vol. 20, No. 2, 2018, pp. 115 - 134.
} 
quirements imposed by the EU law or the Charter. ${ }^{87}$ In this regard, the decisions of the Committee of Ministers rendered in the proceedings for execution of the ECtHR's judgments, may also serve as a valuable source of law on both the compatibility and approximation of domestic laws to the standards guaranteed by the ECHR. Therefore, in spite of a noticeable progress in interpretation and direct application of the Charter in the area of migrations and asylum, the CCC should not lose sight of the comparative method of interpretation implemented in $X$. $Y$. case.

\section{CONCLUDING REMARKS}

From the analysis of the CCC's case law, several conclusions can be reached as to the interpretative methods in application of the Charter:

1. The CCC's pre-accession and early post-accession methodology usually disregarded to answer whether the Charter (the EU law) is applicable in a specific situation ratione temporis or ratione materiae, and on several occasions the CCC had even erred in the assessment of applicability. Furthermore, the CCC has never dealt with issues of vertical and horizontal effect of the Charter's provisions. These observations may appear formalistic, as the Charter or the case law of the CJEU could be consulted as an interpretative tool or a source of law even where the EU law is not applicable. However, establishing the real scope of application of the EU law, and thus the Charter, is a foremost step in honouring the obligation to activate the preliminary reference mechanism pursuant to Art. 267 TFEU.;

2. Regardless of the formalistic approach to the scope of application, the Charter may be applied in every case as a comparative source of law or an interpretative tool. There is, in fact, no need for declaring one's application for constitutional review inadmissible, solely because the applicant had referred to the Charter where the EU law is not applicable.;

3. If the applicant's complaint, as to the compatibility with the requirements stemming from the Charter, is not substantiated, the CCC should not declare it inadmissible where, according to the case law of the ECtHR, is obliged to conduct an examination proprio motu. In other cases, the doctrine on inadmissiblity should be applied consistently, as in the case law of the ECtHR.;

87 As to the limited scope of application of the concept of positive obligation in the EU law, especially in migration related cases, see Beijer, M., The Limited Scope For Accepting Positive Obligations Under EU Law: The Case of Humanitarian Visas For Refugees Review of European Administrative Law, Vol. 11, No. 1, 2018, par. $37-48$. 
4. When interpreting the Charter in a situation where there is no clear case law of the CJEU (the CILFIT criteria) or where the applicant's arguments are posing complex questions on interpretation of the EU law, and the situation obviously falls under the scope of application of the EU law (as in the Consumer Protection Act case), it is advisable to activate the preliminary reference mechanism.;

5. The progress of the CCC in applying the Charter and the EU law in the cases of migrations or asylum is praiseworthy. However, the CCC should verify consistently, by a comparative method, the standards of protection afforded by the ECHR and the Charter, as in the $X$. $Y$. case. Thus especially in the cases of constitutional review in abstracto, even where the contested law is in compliance with the Charter (the EU law), the positive obligations created under Art. 1 ECHR should be honoured and the ECtHR's case law consulted.

\section{REFERENCES}

\section{BOOKS AND ARTICLES}

1. Beijer, M., The Limited Scope For Accepting Positive Obligations Under EU Law: The Case of Humanitarian Visas For Refugees Review of European Administrative Law, Vol. 11, No. 1, 2018, par. 37 - 48

2. Blöndal, E. K.; Arnardóttir, O. M, Non-Refoulement in Strasbourg: Making Sense of the Assessment of Individual Circumstances, Oslo Law Review, Vol. 5, No. 3, 2018, pp. 147 - 174

3. Chlebny, J., Public Order, National Security and the Rights of Third-Country Nationals in Immigration Cases, European Journal of Migration and Law, Vol. 20, No. 2, 2018, pp. 115 $-134$

4. Dzehtsiarou, K., et al., Human Rights Law in Europe: The Influence, Overlaps and Contradictions of the EU and the ECHR, Routledge, New York, 2014

5. Gomboš, K., Europeanisation effects in the court jurisprudence, International and Comparative Law Review, Vol. 19, No 1, 2019, pp. 261 - 275

6. Gragl, P., An Olive Branch from Strasbourg? Interpreting the European Court of Human Rights' Resurrection of Bosphorus and Reaction to Opinion 2/13 in the Avotinš Case: ECtHR 23 May 2016, Case No. 17502/07, Avotinšs v Latvia, European Constitutional Law Review, Vol. 3, No. 3, pp. 551- 567

7. Horvat Vuković, A., The Constitutional Court of the Republic of Croatia as a 'European' Court and the Preservation of National Standards of Fundamental Rights Protection, Zbornik Pravnog fakulteta u Zagrebu, Vol. 69, No. 2, 2019, pp. 249 - 276

8. Kuhnert, K., Bosphorus - Double standards in European human rights protection?, Utrecth Law Review, Vol. 2, No. 2, 2006, pp.177 - 189

9. Ligeti, K., et al., Admissibility of Evidence in Criminal Proceedings in the EU, The European Criminal Law Association's Forum, No. 3, publication by Max Planck Society for the Advancement of Science, Freiburg, 2020, pp. $201-208$ 
10. Materljan, G.; Materljan, I., Predmet Taricco II i pitanja na vagi: ustavno načelo zakonitosti u kaznenom pravu i djelotvornost prava Europske unije, Hrvatski ljetopis za kaznene znanosti i praksu (Zagreb), Vol. 26, No 2., pp. 503 - 528

11. Martines, F., Direct Effect of International Agreements of the European, The European Journal of International Law Vol. 25 no. 1, 2014, pp. 129. -147.

12. Selanec, G., The Role of the Charter in the Croatian Legal Order, in Palmisano G. (ed.), Making the Charter of Fundamental Rights a Living Instrument, Brill Nijhoff, Leiden, 2015, pp. 361-381

13. Smerdel, B., In Quest of a Doctrine: Croatian Constitutional Identity in the European Union, Zbornik Pravnog fakulteta u Zagrebu, Vol. 64 No. 4, 2014, pp. 513 - 554

14. Zalar, B., Comments on the Court of Justice of the EU's Developing Case Law on Asylum, International Journal of Refugee Law, Vol. 25, No.2, 2013, pp. 377 - 381

\section{ECHR}

1. (European) Convention for the Protection of Human Rights and Fundamental Freedoms, Official Gazette, International agreements, No. 18/1997, 6/1999, 14/2002, 13/2003, 9/2005, 1/2006, 2/2010

2. Al-Nashif v. Bulgaria, 50963/99, 20.6.2002.

3. M.S.S. v. Belgium and Greece, 30696/09, GC, 21.1.2011.

4. M.S.S. v. Belgium and Greece (GC), 30696/09, GC, 21.1.2011

5. Michaud v. France, 12323/11, 6.12.2012.

6. De Souza v. France, GC, 22689/07, 13.12.2012.

7. Habulinec and Filipović v. Croatia, 51166/10, 4.6.2013.

8. F.G. v Sweden, 43611/11, GC, 23.3.2016.

9. F.G. v Sweden, 43611/11, GC, 23.3.2016.

10. A. M. v Netherlands, 29094/09, 5.7.2016.

11. J. K. and Others v. Sweden, 59166/12, GC, 23.8.2016.

12. J. K. and Others v. Sweden, 59166/12, GC, 23.8.2016.

13. X. v Sweden, 36417/16, 9.1.2018.

\section{EU LAW}

1. 2008/147/EC: Council Decision of 28 January 2008 on the conclusion on behalf of the European Community of the Agreement between the European Community and the Swiss Confederation concerning the criteria and mechanisms for establishing the State responsible for examining a request for asylum lodged in a Member State or in Switzerland, 2008, OJ L $53 / 3$

2. 2009/487/EC: Council Decision of 24 October 2008 on the conclusion of a Protocol between the European Community, the Swiss Confederation and the Principality of Liechtenstein to the Agreement between the European Community and the Swiss Confederation 
concerning the criteria and mechanisms for establishing the State responsible for examining a request for asylum lodged in a Member State or in Switzerland, 2009, OJ L 161/6

3. Council Directive 93/13/EEC of 5 April 1993 on unfair terms in consumer contracts, 1993, OJ L 95/29

4. Directive 2005/85/EC of 1 December 2005 on minimum standards on procedures in Member States for granting and withdrawing refugee status, 2005, OJ L 326/13

5. Directive 2007/66/EC of the European Parliament and of the Council of 11 December 2007 amending Council Directives 89/665/EEC and 92/13/EEC with regard to improving the effectiveness of review procedures concerning the award of public contracts, 2007, OJ L $335 / 31$

6. Directive 2013/32/EU of the European Parliament and of the Council of 26 June 2013 on common procedures for granting and withdrawing international protection, 2013, OJ L $180 / 60$

7. Directive 2013/33/EU of the European Parliament and of the Council of 26 June 2013 laying down standards for the reception of applicants for international protection (recast), 2013, OJ L 180/96

8. Directive 2014/17/EU of the European Parliament and of the Council of 4 February 2014 on credit agreements for consumers relating to residential immovable property and amending Directives 2008/48/EC and 2013/36/EU and Regulation (EU) No 1093/2010, 2014, OJ L $60 / 34$

9. The Charter of Fundamental Rights of the European Union, 2012, OJ C 326/391

10. Treaty on the Functioning of the European Union, 2012, OJ C 326

\section{CJEU}

1. C-438/05 (Viking), GC, 11.9.2007.

2. C-568/08 (Combinatie Spijker Infrabouw-De Jonge Konstruktie), 9.12.2010.

3. C-34/10 (Brüstle), GC, 18.11.2011.

4. C-69/10 (Diouf), 28.7.2011.

5. C-411/10 and C-493/10 (N. S. and Others), GC, 21.12.2011.

6. C-396/11 (Radu), GC, 29.1.2013.

7. C-105/14 (Taricco I), GC, 8.9.2015.

8. C-483/16 (Sziber), 31.5.2018.

9. C-42/17 (Taricco II), AG's opinion, 18.7.2017.

10. C-42/17 (Taricco II), GC, 5.12.2017.

11. C-180/17 (Staatssecretaris van Veiligheid en Justitie - suspensory effect of the appeal), 26.9.2018.

12. C-277/19 (R. D. and A. D.), 26.9.2019. 


\section{LIST OF NATIONAL REGULATIONS, ACT AND COURT DECISIONS}
a) CROATIAN CONSTITUTIONAL COURT
1. U-I-60/1991 et al. (Termination of pregnancy), 21.2.2017.
2. U-I-448/2009 et al. (Criminal Procedure Act), 19.7.2012.
3. U-I-1007/2012 et al. (Act on Foreigners), 24.6.2020.
4. U-I-5600/2012 (Enforcement Act), 23.4.2013
5. U-I-3826/2013 et al. (Penal Code), 28.11.2017.
6. U-I-3861/2013 (Value Added Tax Act), 16.7.2013.
7. U-III- 351/2014 (Perković), 24.1.2014.
8. U-III-6958/2014 (S. A. K.), 27.2.2018.
9. U-III-1267/2015 (GONG - the right of access to classified informations), 21.11.2017.
10. U-I-1397/2015 (Elections Act), 24.9.2015.
11. U-I-3685/2015 (Consumer Protection Act)
12. U-III-2864/2016 (Đomlija), 23.5.2019.
13. U-I-1092/2017 (Act on Direct Payments for Employment), 10.7.2018.
14. U-I-2911/2017 (Public Procurement Act)
15. U-III-208/2018 (Oral I), 10.7.2018.
16. U-IIIBi-1385/2018 (Hussainkhel I), 18.12.2018.
17. U-I-2855/2018 (Croatian Qualifications Framework), 10.3.2020.
18. U-III-3468/2018 (ORCA)
19. U-III-424/2019 and U-III-1411/2019 (X. Y. - expulsion to Iraq), 17.12.2019.
20. U-III-557/2019 (A. B. - expulsion to Iraq), 11.9.2019.

\section{b) NATIONAL LEGISLATION}

1. The Constitution of the Republic of Croatia, Official Gazette No. 56/1990, 135/1997, 113/2000, 28/2001, 76/2010, 5/2014

2. The Act Ammending the Act on Elections of the Representatives to the Croatian Parliament, Official Gazette, No. 19/2015

3. Act Ammending and Supplementing the Consumer Protection Act, Official Gazette No. $102 / 2015$

4. Act on Foreigners, Official Gazette, No. 130/2011, 74/2013, 69/2017, 46/2018

5. Act on International and Temporary Protection, Official Gazette, No. 70/2015, 127/2017

6. Constitutional Act on the Constitutional Court of the Republic of Croatia. Official Gazette, No. 99/1999, 29/2002 i 49/2002

7. Criminal Procedure Act, Official Gazette, No. 152/2008, 76/2009, 80/2011

8. Penal Code, Official Gazette, No. 25/2011, 144/2012, 56/2015, 61/2015, 101/2017

9. Public Procurement Act, Official Gazette, No. 120/2016

10. Enforcement Act, Official Gazzete, No. 112/2012

11. Value Added Tax Act, Official Gazzete No. 73/13 


\section{WEBSITE REFERENCES}

1. Barić, S. The Transformative Role of the Constitutional Court of the Republic of Croatia - From the ex-Yu to the EU, Working paper for Analitika Center of Social Research, Sarajevo, 2016, [https://bib.irb.hr/datoteka/971606.constitutional_court_croatia_1.pdf], Accessed 3 February 2021

2. ECtHR's Practical Guide on Admissibility Criteria, Council of Europe, Strasbourg, 2021, p. 74., [https://www.echr.coe.int/documents/admissibility_guide_eng.pdf], Accessed 1 April 2021 